\title{
ПРЕЗИДЕНТСЬКІ ТА ПАРЛАМЕНТСЬКІ ВИБОРЧІ КАМПАНІЇ В УМОВАХ ОДНОРІЧНИХ ЕЛЕКТОРАЛЬНИХ ЦИКЛІВ ДОБИ НЕЗАЛЕЖНОСТІ УКРАЇНИ
}

\author{
Яковлєва Н. І., \\ кандидат політичних наук, \\ старший викладач кафедри соціології \\ Національного технічного університету України \\ «Київський політехнічний інститут імені Ігоря Сікорського» \\ Коломієць Т. В., \\ кандидат фрілософрських наук, \\ дочент кафредри соціології \\ Національного технічного університету України \\ «Київський політехнічний інститут імені Ігоря Сікорського» \\ Северинчик О. П., \\ старший викладач кафедри соціології \\ Національного технічного університету України \\ «Київський політехнічний інститут імені Ігоря Сікорського»
}

У статті досліджено три річні виборчі цикли за період незалежності України. У 1994 р., 2014 р. та 2019 р. Президент України й Верховна Рада України обиралися через рік. Основними причинами цих виборів були політичні кризи, що паралізували подальший розвиток держави, та громадські настрої, які не відповідали партійному складу тогочасних виборних органів. Підкреслюється, що з позиції послідовності проведення парламентської та президентської кампаній 1994 р. відрізняється від 2014 р. та 2019 р. У 1994 р. спочатку були проведені парламентські вибори, а потім уже президентські, натомість у 2014 р. та в 2019 р. спочатку проводилися президентські, а потім уже парламентські вибори. Що стосується термінів проведення виборів, то в 1994 р. та в 2014 р. президентська й парламентська кампанії були надзвичайними, натомість у 2019 р. президентська кампанія була регулярною, а парламентська - надзвичайною. Аналізуються виборчі системи, які застосовувалися в межах однорічних виборчих циклів. На виборах Президента України виборча система - мажоритарна - залишалася незмінною впродовж періоду незалежності України. Водночас стосовно виборів до парламенту в 1994 р. використовувалася мажоритарна система, а в 2014 р. та в 2019 р. - змішана виборча система (50\% мажоритарна і 50\% пропорційна з 5-відсотковим бар'єром для політичних партій). Зазначено, що технологічно президентські кампанії Л. Кравчука та Л. Кучми в 1994 р. ґрунтувалися на електоральних установках парламентських виборів. Однак у 2014 р. та в 2019 р. вибори до Верховної Ради України були логічним продовженням президентських виборів за збереження основної стратегії й основних гасел кампаній політичних партій. Уточнено, що запит на радикальне реформування влади, швидке перезавантаження політичної системи та антиелітні настрої $€$ актуальними світовими тенденціями, які відповідають українським реаліям, що було продемонстровано завдяки обранню В. Зеленського Президентом України та високому рівню виборчої довіри до нової партії «Слуга народу» в 2019 р.

Ключові слова: вибори, виборча кампанія, вибори президента, парламентські вибори, Президент України, Верховна Рада України, електоральний цикл.

Постановка проблеми. Українська електоральна історія періоду незалежності зараз налічує сім президентських виборчих кампаній (1991р., 1994 р., 1999 р., 2004-2005 рр., 2010 р., 2014 р., 2019 р.) та вісім парламентських виборчих кампаній (1994 р., 1998 р., 2002 р., 2006 р., 2007 р., 2012 р., 2014 р., 2019 р.). Їх кількість свідчить насамперед про те, що низка виборів були позачерговими через особливі обставини соціально-політичної ситуації в державі. 3 одного боку, владні кола у своїх протистояннях та прийнятті суперечливих рішень входили у стадію гострої кризи, паралізуючи дієздатність 
державного апарату, а з іншого - електорат був розчарований таким станом речей і висував свій запит на оновлення політичних еліт через механізм прямої демократії.

У цьому контексті є три прецеденти в історії незалежності нашої держави, коли вибори Президента України та Верховної Ради України відбувалися в один рік, зокрема: у 1994 р., у 2014 р. та в 2019 р. Загалом час проведення президентських і парламентських виборів визначений у Конституції України. Зокрема, за чинною редакцією Конституції України у ст. 103 вказано, що чергові вибори Президента України проводяться в останню неділю березня п'ятого року повноважень. А ст. 77 Конституції України передбачає, що чергові вибори до Верховної Ради України відбуваються в останню неділю жовтня п'ятого року повноважень Верховної Ради України [1].

Варто зазначити, що за часів дії редакції Конституції України, що відповідала президентсько-парламентській республіці, строк повноважень Президента України становив 5 років, а строк повноважень парламенту - 4 роки. Проте через одноразові випадки призначення дострокових виборів в Україні ситуацію, коли в один рік відбуваються і президентські, і парламентські вибори, можна вважати рідкісною, а отже, такою, що потребує окремого дослідження.

Аналіз останніх досліджень і публікацій. Коло наукових пошуків щодо виборчих процесів в Україні завжди було широким. Однак електоральні кампанії 1994 р., 2014 р. та 2019 р. досліджували У. Гев'юк [2], А. Колодій [3], І. Корж [4], Б. Руснак [5], К. Турчинов [6]. У контексті вивчення електоральних циклів працюють вітчизняні вчені В. Бунь [7], Л. Ткаченко [8], Н. Ротар [9]. Що стосується західних дослідників, то до історії виборів в Україні системний науковий інтерес проявляє Е. Херрон [10].

Проте велика кількість досліджень щодо електоральної проблематики не дає концептуального розуміння визначення виборчих прецедентів 1994 р., 2014 р. та 2019 р. 3 огляду на це метою статті $€$ розкриття взаємовпливів українських президентських і парламентських виборчих кампаній в умовах однорічних електоральних циклів.

Для досягнення поставленої мети необхідно виконати такі завдання: виокремити особливості виборчих кампаній 1994 р., 2014 р. та 2019 р. в Україні; визначити кореляції між стратегіями президентських і парламентських кампаній в однорічний електоральний цикл; оцінити реалізацію запиту громадян на оновлення політичної еліти через механізм перезавантаження інститутів публічної влади.

Виклад основного матеріалу. У дослідженні варто розглянути два базові наукові поняття. Першим із них є термін «виборча кампанія». Вітчизняна дослідниця Т. Мадрига характеризує виборчу кампанію як «законодавчо встановлений проміжок часу, протягом якого політичні суб'єкти (кандидат, партія чи блок партій) повинні позиціонувати себе в очах виборців, привернути до себе увагу електорату (об'єкта свого впливу) і спонукати людей проголосувати за кандидата тієї чи іншої політичної орієнтації, яка обіцяє своєму сегменту електорату певні соціальні вигоди» [11].

У цьому ж контексті пропонується авторське визначення наукової категорії «виборча кампанія»: це сукупність методів і заходів організаційно-агітаційного, медійно-аналітичного та юридичного змісту, що спрямовані на досягнення позитивного електорального результату партією чи кандидатом.

Друге поняття, яке є важливим для розгляду окресленої проблематики, - «електоральний цикл». Так, Н. Ротар пропонує розглядати його як сукупність взаємодій між політичними суб'єктами з приводу здійснення публічної політики в їх логічній динамічній послідовності. Відповідно до цього електоральний цикл, на переконання науковця, має три фрази: 1) передвиборчий етап - етап цілеспрямованої підготовки до виборів, під час якої основні актори електорального процесу визначають стратегію й тактику передвиборної боротьби, працюють з електоратом, а останній використовує специфічні форми політичної участі, що передують електоральному вибору; 2) етап виборів - етап активних дій основних інституційних суб'єктів електорального змагання та громадян як суб'єктів виборчого процесу; 3) поствиборчий етап - етап відкритого загальнонаціонального політичного дискурсу, що $€$ переважно пасивною підготовкою до виборів (він починається з моменту закінчення попередніх виборів і завершується з початком передвиборчого етапу) [9, с. 8-9].

Дослідниця дуже точно акцентує увагу на тому, що електоральний цикл не вичерпується юридичними строками проведення виборчої кампанії, а охоплює значно ширший період, у тому числі первинну підготовку до виборчого процесу та період післявиборчої активності, а також закладення підвалин для майбутніх електоральних процесів у діяльності партії чи кандидата. У випадках виборів 1994 р., 2014 р. та 2019 р. електоральні цикли практично накладаються один на одного.

Необхідно зауважити, що обрання протягом одного року глави держави та парламенту спричинює концентрацію агітаційної діяльності політичних суб'єктів, наявність гострої й виснажливої боротьби між конкурентами у владних колах, перенасиченість залучення електорату до участі у прямій демократії. Тобто політичні актори вичерпують організаційні, фрінансові та особистісні ресурси в короткий проміжок часу, а громадяни стомлюються від постійного включення у процес прийняття важливих рішень.

ВІСНИК НТУУ «КПІ». Політологія. Соціологія. Право. Випуск 4 (44) 2019 
Якщо порівнювати три однорічні електоральні цикли періоду незалежності України, то насамперед варто виокремити причини, за яких президентські та парламентські вибори проводилися в один рік. У 1994 р. спочатку 27 березня були проведені позачергові парламентські вибори, а потім позачергові президентські вибори, другий тур яких відбувся 10 липня. Витоками призначення цих двох позачергових виборів були страйки шахтарів через масштабну фінансову кризу [6, с. 14].

На той час вибори Президента України вже відбувалися в незалежній Україні, проте парламентські вибори не проводилися, тому фрактично працював склад депутатів, що був обраний ще за часів Української РСР. Мітингувальники висували насамперед вимогу переобрання Верховної Ради України. Тобто тиск громадянського суспільства на органи влади привів у дію механізм перезавантаження тогочасних політичних еліт.

Зіставляючи однорічні електоральні цикли, варто зазначити, що лише в 1994 р. спочатку відбувалися парламентські вибори, а потім - президентські. У 2014 р. та 2019 р. було навпаки: спочатку відбувалися президентські вибори, а після - парламентські. У 2014 р. позачергові вибори були викликані безпрецедентними політичними обставинами через Революцію гідності, втечу В. Януковича з України, анексію Криму та військові дії на території Донецької й Луганської областей. Юридичною підставою проведення позачергових виборів було визначено самоусунення Президента України від виконання конституційних обов'язків [12]. Президентські вибори пройшли в один тур, перемогу на них отримав П. Порошенко з результатом 54,7\% голосів виборців [13]. Варто зауважити, що в електоральній історії України поки що тільки двічі кандидат на пост Президента України перемагав у першому турі: Л. Кравчук у 1991 р. та П. Порошенко у 2014 р.

Парламентські позачергові вибори у 2014 р. були призначені указом П. Порошенка через відсутність коаліції протягом одного календарного місяця [14] та відбулися 26 жовтня. Однак підірунтям для цієї підстави став спланований вихід фрракцій «УДАР Віталія Кличка» та «Свобода» з парламентської коаліції, тому насамперед необхідно говорити про політичні причини призначення дострокових виборів [15]. У суспільстві був запит на оновлення складу парламенту, який на той час не відповідав електоральним настроям. Окрім того, партія «Блок Петра Порошенка», яка фрормувалася швидкими темпами після перемоги її лідера, прагнула призначення позачергових виборів через високий політичний рейтинг П. Порошенка з метою посилення представництва в депутатському корпусі.

У 2019 р. президентські вибори були черговими. Перемогу у другому турі виборів отримав В. Зеленський - кандидат, який не мав попереднього політичного досвіду, на противагу головному конкуренту - П. Порошенку. Результат голосування виборців В. Зеленського в 73,2\% підтримки [16] став виявом запиту виборців на «справжність образу політика» та на оновлення політичної влади. Далі В. Зеленський пішов за попереднім сценарієм П. Порошенка та своїм указом оголосив дострокові парламентські вибори так само через відсутність коаліції в парламенті протягом 30 днів [17]. Проте у 2019 р. підстави для такого рішення були більш сумнівними, адже сама коаліція розпалася ще у 2016 р., а парламент залишався дієздатним і приймав рішення. Відповідно, Конституційний Суд України надав висновок щодо обґрунтованості указу Президента України та визнав його конституційним [18]. Фактично причинами призначення цих виборів у політичному сенсі були ті ж складники, що й у 2014 р.: запит населення на стрімкі зміни у владних колах і посилення позицій пропрезидентської партії «Слуга народу».

У проміжному підсумку, якщо розглядати часовий характер виборів, то варто зазначити, що в 1994 р. та у 2014 р. президентські й парламентські вибори були позачерговими, проте у 2019 р. президентські вибори були черговими, а парламентські - позачерговими.

Водночас питання послідовності проведення виборів потребує більш детального розгляду щодо взаємовпливів ходу електоральних кампаній. Парламентські вибори 1994 р. були першими в історії України, окрім того, вони лише одного разу відбувалися за мажоритарною системою абсолютної більшості. За результатами виборів 27 березня 1994 р. вдалося закрити лише 338 депутатських мандатів, а низку кандидатів обирали аж до кінця квітня 1996 р. [4, с. 93].

У 1994 р. за партійною приналежністю найбільшу кількість мандатів здобула Комуністична партія України на чолі з лідером П. Симоненком. Однак якщо взяти за загальною кількістю мандатів, то перше місце здобули самовисуванці - аж 168 мандатів. Це свідчило про строкатість електоральних настроїв у регіонах України та про майбутню складну політичну конфрігурацію парламенту [2, с. 79].

У цьому випадку президентська кампанія слідувала за парламентською, тому кандидатам на пост Президента України можна було спиратися на електоральні настрої населення виборів до Верховної Ради України. Проте Л. Кравчук зробив стратегічну ставку на суто проукраїнські меседжі й риторику, тому програв Л. Кучмі, який будував свою кампанію на таких слоганах: «Кучма: порядок, праця і порядність» [19], «За президента Кучми твоє підприємство працюватиме», «Україна - Росія: менше річок, більше мостів» [20]. Такий підхід Л. Кучми посприяв мобілізації південних і східних областей України у другому турі виборів. 
Два інші однорічні електоральні цикли (2014 р. і 2019 р.) відрізняються тим, що стратегія парламентських виборів більшості політичних партій вибудовувалася в контексті перемоги на посаду Президента України П. Порошенка чи В. Зеленського. Тобто це була трансформація з однієї виборчої фази в іншу задля оновлення представницьких органів влади. В організаційному аспекті такі електоральні цикли є досить зручними: партійні організації або виборчі штаби мобілізовані, стратегії дій із базовими механізмами підлягають екстраполяції, схеми агітаційної роботи налагоджені. Проте успіх конвертації попередніх досягнень на президентських виборах у голоси виборців на парламентських завжди залишається полем для політтехнологічної роботи та для виправдання електоральних сподівань виборців у перші місяці роботи на посту новообраного Президента України [10, с. 427].

Основним меседжем П. Порошенка на президентських виборах 2014 р. було гасло «Жити по-новому» [21]. Через ідею безальтернативності щодо інших кандидатів, яка втілювалася в концепті «Обери мир - обери Порошенка», у парламентську кампанію вийшли на базовий стрижень «Час єднатись» [22]. Україна тоді перебувала у фазі гострого збройного протистояння, тому ідея консолідації нації була найбільш прийнятною для суспільства.

Меседж виборчої кампанії В. Зеленського у 2019 р. був «Президент - слуга народу», а перед другим туром виборів у період мобілізаційної фрази він був сформульований як «Зробимо це разом» або «Зробимо їх разом» [23]. Під цим розумівся концепт, що відображав суспільні настрої: не дамо досвідченим, «старим» політикам знову здобути владу. Цей стрижень був дуже вдало трансформований у період парламентської кампанії: «Зе!Депутат - слуга народу» [24], «Зробимо їх ще раз».

У політтехнологічному сенсі парламентські вибори 2014 та 2019 рр. були продовженням президентських кампаній відповідних років. Базова стратегія вибудовувалася на тому, що президенту потрібна команда, яка здатна реалізувати стратегічний курс та закріпити його на законодавчому рівні.

Щодо системи виборів, то всі вибори Президента України проходили за мажоритарною системою абсолютної більшості. Парламентські вибори за умов однорічних електоральних циклів відбувалися таким чином: у 1994 р. - за мажоритарною системою абсолютної більшості, у 2014 р. та у 2019 р. за змішаною виборчою системою, де 50\% депутатів обирається за мажоритарною системою відносної більшості в одномандатних виборчих округах і 50\% - за пропорційною виборчою системою в загальнодержавному багатомандатному окрузі з 5-відсотковим прохідним виборчим бар'єром [25].

До речі, ця виборча система у 2014 та 2019 рр. дала бонуси для пропрезидентських партій. Зокрема, за партійними списками «Блок Петра Порошенка» у 2014 р. здобув друге місце з результатом 21,82\% голосів виборців [26], проте низка перемог на мажоритарних виборчих округах суттєво додала депутатських мандатів у Верховній Раді України 8 скликання, що дозволило БПП стати найбільшою за чисельністю фракцією. Загалом ця кількість на початку каденції склала 203 народні депутати. Проте цього не було досить для формування парламентської більшості, тому відбулися перемовини фрракцій Верховної Ради України, у результаті яких була утворена коаліція «Європейська Україна», до якої увійшла конституційна більшість депутатів [27].

У 2019 р. вперше в історії українського парламентаризму партія «Слуга народу» за результатами виборів здобула монобільшість. Це стало можливим завдяки сумарному результату застосування змішаної виборчої системи. За партійними списками «Слуга народу» здобула 43,16\% голосів виборців [28], а також більшість перемог кандидатів на мажоритарних виборчих округах, що сумарно склало 254 депутатські мандати. Такий стан речей спричинив відсутність необхідності фоормвання парламентської коаліції.

Варто зазначити, що 19 грудня 2019 р. парламент подолав вето Президента України на Виборчий кодекс України, що був прийнятий Верховною Радою України 11 липня 2019 р., і 27 грудня В. Зеленський підписав остаточну редакцію. Згідно із цим актом ліквідовується застосування змішаної виборчої системи виборів до парламенту та вступає в силу пропорційна система з відкритими списками [29].

На виборах 2014 та 2019 рр. базовим запитом електорату була вимога «справжності» політика, що полягає у відповідності обіцянок у період виборчої кампанії подальшим політичним діям. Під час парламентських кампаній у 2014 та 2019 рр. відбувалося екстраполювання позитивних якостей Президента України та його меседжів на кандидатів у передвиборчих списках «Блоку Петра Порошенка “Солідарність”» і «Слуги народу» відповідно через кредит електоральної довіри, що забезпечило позитивний результат депутатськими мандатами.

Висновки. Підбиваючи підсумки дослідження однорічних електоральних циклів історії незалежної України, варто звернути увагу на те, що були три такі прецеденти в 1994 р., 2014 р. та 2019 р., які були пов'язані з особливими соціально-політичними обставинами. Головними причинами цих виборів можна назвати політичні кризи, які паралізували подальший розвиток держави, та суспільні настрої, що не відповідали партійному складу тогочасних діючих виборних органів влади.

В аспекті послідовності протікання парламентських і президентських кампаній 1994 р. є відмінним від 2014 р. та 2019 р. У першому випадку спочатку за строками проведення були парламентські вибори, а потім - президентські, натомість у другому й третьому випадках навпаки: прези- 
дентські вибори передували парламентським. Щодо чинника строковості виборів варто зауважити, що в 1994 р. та у 2014 р. позачерговими були і президентські, і парламентські виборчі кампанії, натомість у 2019 р. президентська кампанія була черговою, а парламентська - позачерговою.

Варто також зіставити виборчі системи, які застосовувалися в умовах однорічних електоральних циклів. Виборча система щодо обрання Президента України $є$ незмінною впродовж усього періоду незалежності України - мажоритарна система абсолютної більшості. Водночас щодо виборів до парламенту в 1994 р. використовувалася мажоритарна система абсолютної більшості, а у 2014 р. та у 2019 р. - змішана виборча система (50\% мажоритарна і 50\% пропорційна).

Усі наведені чинники в контексті політичних конфрігурацій приводили до того, що технологічно президентська виборча кампанія Л. Кравчука та Л. Кучми в 1994 р. будувалася на врахуванні електоральних настроїв парламентських виборів, проте у 2014 та 2019 рр. вибори до Верховної Ради України були логічним продовження виборів Президента України зі збереженням базової стратегії й головних меседжів.

Запит на радикальне оновлення влади, швидке перезавантаження політичної системи та антиелітарні настрої є сучасними світовими трендами, яким відповідають українські реалії через обрання В. Зеленського Президентом України та високий рівень електоральної довіри до новоутвореної партії «Слуга народу» у 2019 р. У міжнародному контексті це є виявом необхідності формування нового політичного світогляду й базового усвідомлення творення прозорого концепту державного управління.

Варто зазначити, що якщо не будуть призначатися позачергові президентські чи парламентські вибори, то в умовах чинної Конституції України та Виборчого кодексу України чергові вибори будуть завжди проводитися в однорічний електоральний цикл. Відповідно, такі прецеденти, як це було в 1994, 2014 та 2019 рр., перестануть бути особливими. Проте українська електоральна історія завжди має певний аспект наукової, юридичної та політичної непередбачуваності.

Yakovlieva N., Kolomiiets T., Severynchyk O. The presidential and parliamentary election campaigns in the conditions of one-year electoral cycles in the independent Ukraine

In this article, three one-year electoral cycles during the Independence of Ukraine have been researched. In 1994, 2014 and 2019 the President of Ukraine and the Verkhovna Rada of Ukraine were elected in one year. The main causes of these elections were political crises that paralyzed the further development of the state and public attitudes that did not match the party composition of the current electoral authorities.

It is emphasized that in terms of the sequence of conducting parliamentary and presidential campaigns 1994 is different from 2014 and 2019. In 1994 parliamentary elections were first conducted and then the presidential elections, in 2014 and 2019, on the contrary: presidential and then parliamentary. In terms of the timing of the elections, in 1994 and 2014 the presidential and parliamentary election campaigns were extraordinary and in 2019 the presidential campaign was regular and the parliamentary one was extraordinary.

The election systems that have been applied under one-year electoral cycles are analyzed. At the election of the President, the electoral system has remained unchanged during Ukraine's Independence period - the majoritarian system. At the same time, in relation to the elections to parliament: in 1994 a majoritarian system was used and in 2014 and 2019 - a mixed electoral system (50\% majority and $50 \%$ proportional with a $5 \%$ barrier for political parties).

It has been outlined that technologically presidential campaigns of L. Kravchuk and L. Kuchma in 1994 were based on the electoral attitudes of the parliamentary elections, but in 2014 and 2019 elections to the Verkhovna Rada of Ukraine were a logical continuation of the presidential elections while maintaining the basic strategy and main messages of the political parties campaigns.

It have been clarified that the request for a radical reformation of authority, a quick reboot of the political system and anti-elite attitudes are the current world trends which are in line with Ukrainian realities through the election of V. Zelensky as President of Ukraine and a high level of electoral confidence in the new party "Servant of the people" in 2019.

Key words: elections, election campaign, presidential elections, parliamentary elections, President of Ukraine, Verkhovna Rada of Ukraine, electoral cycle.

\section{Література:}

1. Конституція України : Закон України від 28 червня 1996 р. № 254к/96-ВР / Верховна Рада України. URL: https://zakon.rada.gov.ua/laws/show/254\%D0\%BA/96-\%D0\%B2\%D1\%80 (дата звернення: 29.10.2019).

ВІСНИК НТУУ «КПІ». Політологія. Соціологія. Право. Випуск 4 (44) 2019 
2. Гев'юк У. Позачергові парламентські вибори 1994 та 2007 рр. в Україні: порівняльний аналіз. Науковий вісник Ужгородського університету. Серія «Політологія. Соціологія. Філософрія». 2010. Вип. 14. С. 78-82.

3. Колодій А. Позачергові президентські й парламентські вибори 2014 року в Україні: особливості та наслідки. URL: http://political-studies.com/?p=1263 (дата звернення: 29.10.2019).

4. Корж І. Вибори в незалежній Україні. Вісник Центральної виборчої комісії. 2007. № 1(7). С. 93-95.

5. Руснак Б. Особливості проведення позачергових виборів народних депутатів 26 жовтня 2014 року. URL: http://buk-visnyk.cv.ua/naukova-dumka/329/ (дата звернення: 29.10.2019).

6. Турчинов К. Окремі недоліки національного виборчого законодавства в контексті європейської інтеграції України. Наукові записки Інституту законодавства Верховної Ради України. 2015. № 3. С. 14-19.

7. Бунь В. Теоретичне визначення форм електоральної суб'єктності. Вісник Львівського університету. Серія «Філософрсько-політологічні студії». 2015. Вип. 6. С. 286-294.

8. Ткаченко Л. Електоральний простір та електоральне поле: теоретичне дослідження понять. Гуманітарні студії: збірник наукових праць. 2012. Вип. 15. С. 256-263. URL: http://hstudies-univ.kiev.ua/images/HSarchive/HStudiesKNU15.pdf (дата звернення: 29.10.2019).

9. Ротар Н. Циклічні політичні процеси в Україні трансформаційного періоду: методологічні проблеми дослідження та викладання. Українська національна ідея: реалії та перспективи розвитку. 2006. Вип. 17. С. 8-12. URL: http://ena.lp.edu.ua/bitstream/ntb/7823/1/02.pdf (дата звернення: 29.10.2019).

10. Herron E., Thunberg M., Boyko N. Crisis management and adaptation in wartime elections: Ukraine's 2014 snap presidential and parliamentary elections. Electoral Studies. 2014. Vol. 40. P. 419-429.

11. Мадрига Т. Наукові підходи та методологія дослідження виборчої кампанії в зарубіжній політичній науці. Науковий вісник Ужгородського університету. Серія «Політологія, Соціологія, Філософрія». 2009. Вип. 13. С. 310-313.

12. Про самоусунення Президента України від виконання конституційних повноважень та призначення позачергових виборів Президента України : Постанова Верховної Ради України від 22 лютого 2014 р. № 757-VII / Верховна Рада України. Відомості Верховної Ради України. 2014. № 11. Ст. 158. URL: https://zakon.rada.gov.ua/laws/show/757-18 (дата звернення: 29.10.2019).

13. Позачергові вибори Президента України 25 травня 2014 року. Результати голосування по Україні. URL: http://www.cvk.gov.ua/pls/vp2014/wp001 (дата звернення: 29.10.2019).

14. Про дострокове припинення повноважень Верховної Ради України та призначення позачергових виборів : Указ Президента України від 27 серпня 2014 р. № 690/2014 / Президент України. URL: https://www.president.gov.ua/documents/6902014-17590 (дата звернення: 29.10.2019).

15. Голова Верховної Ради України Олександр Турчинов офіційно оголосив про припинення діяльності коаліції «Європейський вибір» у Парламенті. Офіційний вебпортал парламенту України. URL: http://mportal.rada.gov.ua/news/Povidomlennya/96339.html (дата звернення: 29.10.2019).

16. Вибори Президента України - 2019. Результати голосування по Україні 31 березня 2019 р. URL: https://cvk.gov.ua/pls/vp2019/wp300pt001f01=720.html (дата звернення: 29.10.2019).

17. Про дострокове припинення повноважень Верховної Ради України та призначення позачергових виборів : Указ Президента України від 21 травня 2019 р. № 303/2019 / Президент України. URL: https://www.president.gov.ua/documents/3032019-27121 (дата звернення: 29.10.2019).

18. Конституційний Суд України визнав конституційним Указ Президента «Про дострокове припинення повноважень Верховної Ради України та призначення позачергових виборів». URL: http://www.ccu.gov.ua/novyna/ksu-vyznav-konstytuciynym-ukaz-prezydenta-pro-dostrokoveprypynennya-povnovazhen-verhovnoyi (дата звернення: 29.10.2019).

19. Семиженко А. Від Чорновола до Тимошенко: технології українських виборів у 12 історіях. Частина 1. Інтернет-видання «Insider». 2017. 15 серпня. URL: http://www.theinsider.ua/ politics/5992f82e517b9/ (дата звернення: 29.10.2019).

20. Онищенко В. Українська трагедія. Леонід Кучма. Частина I/ за ред. Б. Мацюк. Інтернетвидання «Волинські новини». 2016. 21 лютого. URL: https://www.volynnews.com/blogs/poblyzulutska-rozkopaly-zakhoronennia-pershoyi-svitovoyi-/ukrayinska-trahediia-leonid-kuchma-chastyna-i/ (дата звернення: 29.10.2019).

21. Передвиборча програма кандидата в Президенти України Петра Порошенка 2014 року. URL: https://programaporoshenka.com/Programa_Poroshenko.pdf (дата звернення: 29.10.2019).

22. Час єднатись: з чим БПП йшов до BPУ. URL: http://politconsultant.org/chas-yednatis-z-chim-bppjshov-do-vru/ (дата звернення: 29.10.2019).

23. Офріційний сайт Зе!Команди. URL: https://www.zeteam.info/graphics.html\#gallery[pageGallery]/1/ (дата звернення: 29.10.2019). 
24. Офріційний сайт 3e!2019. URL: https://ze2019.com/blog/partiya_sluha_narodu (дата звернення: 29.10.2019).

25. Про вибори народних депутатів : Закон України від 17 листопада 2011 р. № 4061-VI / Верховна Рада України. URL: http://zakon2.rada.gov.ua/laws/show/4061-17 (дата звернення: 29.10.2019).

26. Позачергові вибори народних депутатів України 26 жовтня 2014 року. Результати по Україні. URL: https://www.cvk.gov.ua/pls/vnd2014/wp300pt001f01=910.html (дата звернення: 29.10.2019).

27. Угода про коаліцію депутатських фракцій «Європейська Україна» : угода від 27 листопада 2014 р. / Верховна Рада України восьмого скликання. URL: https://zakon.rada.gov.ua/laws/show/ n0001001-15 (дата звернення: 29.10.2019).

28. Позачергові вибори народних депутатів України - 2019. Результати по багатомандатному виборчому округу. URL: https://www.cvk.gov.ua/pls/vnd2019/wp300pt001f01=919.html (дата звернення: 29.10.2019).

29. Виборчий кодекс України : Закон України від 19 грудня 2019 р. № 396-ІХ / Верховна Рада України. URL: https://zakon.rada.gov.ua/laws/main/396-IX. 